\title{
Longitudinal clustering of tuberculosis incidence and predictors for the time profiles: the impact of HIV
}

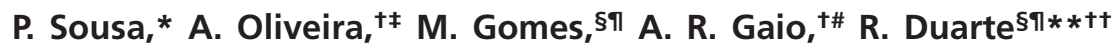 \\ ${ }^{*}$ Faculty of Medicine of Porto University, Porto, ${ }^{+}$Centre of Mathematics, University of Porto, Porto, ${ }^{\ddagger}$ School of \\ Allied Health Sciences, Polytechnic Institute of Porto, Vila Nova de Gaia, §Epidemiology Research Unit Institute of \\ Public Health, University of Porto, Porto, "Centro Hospitalar de Vila Nova de Gaia/Espinho EPE, Vila Nova de Gaia, \\ \#Mathematics Department, Faculty of Sciences, University of Porto, Porto, **Chest Disease Centre, Vila Nova de \\ Gaia, ${ }^{+}$Department of Clinical Epidemiology, Predictive Medicine and Public Health, University of Porto Medical \\ School, Porto, Portugal
}

S U M M AR Y

BACKGROUND: Portugal remains the country with the highest tuberculosis (TB) incidence in Western Europe. OBJECTIVES: To identify longitudinal trends in TB incidence in Portugal from 2002 to 2012 and investigate the longitudinal effect of sociodemographic and healthrelated predictors among the resident population on the TB incidence rate.

MEтHODS: We used data from the National Tuberculosis Surveillance System and other national institutions. Kmeans longitudinal clustering algorithm was performed on TB incidence time profiles from districts of Portugal. RESULTS: Three longitudinal profiles for the TB incidence rate of Portugal were identified. In all of them, TB incidence decreased over time. Among all studied sociodemographic and health-related predictors, human immunodeficiency virus (HIV) notification rate and unemployment were shown to have (positive) significant effects on TB incidence. In particular, the greatest effects were found for the HIV notification rate.

CONCLUSIONS: Our study supports the view that combined TB-HIV strategies and the improvement of social determinants can contribute to decreases in TB incidence.

KEY WORDS: human immunodeficiency virus; AIDS; public health; tuberculosis; unemployment
TUBERCULOSIS (TB) remains a global public health problem, and is currently the second most common cause of death due to an infectious disease. ${ }^{1}$ Despite decreasing trends in TB incidence since 2002, Portugal remains the country with the highest incidence rate in Western Europe. ${ }^{2,3}$ In 2009, in low-incidence countries of the European Union and the European Economic Area, $27.0 \%$ of TB cases occurred in big cities, although only $12.8 \%$ of the population lived there. ${ }^{4}$ In Portugal, TB also has a heterogeneous distribution, affecting mainly the districts of Porto and Lisbon. $^{2}$ A national spatial analysis of continental Portugal at the municipal level between 2000 and 2004 found clustering around the major urban areas in the districts of Porto, Lisbon and Setúbal. ${ }^{5}$

Several epidemiological studies of the spatial analysis of TB incidence have been conducted in recent years. ${ }^{6-8}$ These studies were performed at different levels-national, regional and municipalto establish associations with the socio-economic, demographic and behavioural data of the resident population. ${ }^{6-8}$ The methodologies differ considerably, the time period covered is generally less than a decade and, due to difficulties in gathering data, the variables analysed present certain limitations. Very few studies have been conducted countrywide, but this has been done in Spain, ${ }^{9}$ Brazil $^{6}$ and Portugal. ${ }^{10}$ The study in Portugal was a municipal-level analysis from 2004 to 2006 to identify high risk areas for TB. No longitudinal studies analysing the effect of variations in characteristics of the resident population on TB incidence rate were found.

The aim of the present study was to identify the main longitudinal trends in TB incidence in Portugal from 2002 to 2012 and to investigate the effect of socio-demographic and health-related predictors, particularly human immunodeficiency virus (HIV) infection, of the resident population on the time profiles identified.

\section{METHODS}

\section{Data and sources}

This longitudinal study included every active new TB case notified between 1 January 2002 and 31 December 2012. The data source was the Portuguese

Correspondence to: Raquel Duarte, Instituto de Saúde Pública da Universidade do Porto, Rua das Taipas n 135 , 4050-600 Porto, Portugal. e-mail: raquel.duarte@chvng.min-saude.pt

Article submitted 19 June 2015. Final version accepted 21 March 2016. 
Tuberculosis Surveillance System (Sistema de Vigilância da TB, SVIG TB) and the information was up to date as of 31 December 2012. The SVIG-TB is supervised by the Directorate General of Health (DGS). TB notification is mandatory in Portugal, and reporting coverage has been estimated at $84-93 \% .^{1}$

The Portuguese sociodemographic and healthrelated indicators considered in the study were as follows: 1) working age population: the proportion aged 15-64 years; 2) elderly population: the proportion aged $\geqslant 65$ years; 3 ) unemployment: the proportion registered with the employment office as of 31 December for each year; 4) incarcerated persons: the proportion of existing inmates as of 31 December for each year; 5) prison overcrowding: the percentage of excess inmates (number of inmates - prison capacity)/ prison capacity; 6) HIV notification rate; 7) use of alcohol or other drugs: the proportion of users with medical appointments for treatment for addiction provided by the public health system due to alcohol or other drug use at least once for each year; 8) physicians: the proportion of physicians or surgeons of any employment status in the population; and 9) medical appointments: the proportion of medical appointments at health centres from all clinical specialities in the population.

All proportions were multiplied by 100000 population. For all predictors, data were collected yearly and obtained from the following national institutions: Statistics Portugal (Instituto Nacional de Estatística, INE), Employment and Vocational Training Institute (Instituto do Emprego e Formação Profissional, IEFP), Directorate General of Prison Services (Direcção Geral Dos Serviços Prisionais, DGSP), Institute of Drugs and Drug Addiction (Instituto da Droga e da Toxicodependência, IDT) and the National Health Institute Doutor Ricardo Jorge (Instituto Nacional de Saúde, INSA) (Appendix Table A.1).*

The study assessed the 18 districts in continental Portugal and the Autonomous Region of Madeira based on the territorial classification in the 2010 map of Portugal (Carta Administrativa Oficial de Portugal 2010). The Autonomous Region of Azores was excluded due to the absence of data before 2007. Continental Portugal is administratively divided into 18 districts, while the Autonomous Region of Madeira, located in the Atlantic Ocean, has two inhabited islands. Of the 18 districts, Lisbon is the most populous, with an estimated population of 2252719 (2011 Census).

Because we used published retrospective surveillance data without the possibility of linking patient

\footnotetext{
"The appendix is available in the online version of this article, at http://www.ingentaconnect.com/content/iuatld/ijtld/2016/ 00000020/00000008/art00009
}

records to patient personal data, ethical approval was not necessary for this retrospective study.

\section{Statistical analysis}

The K-means longitudinal clustering algorithm was performed on the time profiles of TB incidence rate in the 19 districts. ${ }^{11}$ Two- and three-cluster structures, each with 40 randomly chosen starting points, were considered. The final number of clusters was chosen based on the epidemiological interpretation of the groups identified and on the statistical criteria of Calinsky \& Harabatz and Davies \& Bouldin (Figure 1). ${ }^{12}$

Apart from the time and the cluster structure identified, those predictors assumed to have a potential longitudinal effect on the TB incidence were HIV notification rate, unemployment, incarceration, prison overcrowding, alcohol or drug use, working age population, elderly population, number of physicians, number of medical appointments and interactions of these covariates with the cluster structure.

Data were grouped by district and autonomous region. The changes over time for HIV notification and the unemployment rates, adjusted for the clusters structure, were assessed by multiple regression fitted using generalised least squares (GLS), allowing for heteroscedastic and correlated errors. The longitudinal effect of the collected sociodemographic and health-related predictors on the TB incidence rate was also studied using GLS. The best variance-covariance matrix was that with a time autocorrelation structure of order 1. On graphic analysis, homoscedasticity and normality of the model residuals did not seem to be compromised. Model comparisons were based on the likelihood ratio test, whenever possible, and on the Bayesian information criterion (BIC) otherwise.

All statistical analyses were performed using the $\mathrm{R}$ language and software environment for statistical computation, version 3.1.2 (R Computing, Vienna, Austria). The significance level was fixed at 0.05.

\section{RESULTS}

During the period studied, a total of 33394 new cases were notified. Males accounted for $67 \%$ of the total; the mean age was 44.09 years (standard deviation 18.57). TB cases with alcohol or other drug addictions represented $23 \%$ of the total. HIV co-infection, whether reported by patients or confirmed through serology, was present in $14 \%$ of all TB cases; however, the serological status was unknown in $26 \%$ of TB cases; $14 \%$ of patients were foreignborn; $4 \%$ were homeless or were living in community residences; and $2 \%$ had a past or current history of incarceration.

The two districts with the largest urban areas (Porto and Lisbon) consistently presented the highest TB incidence rate throughout the entire period evaluated; five other regions shared the lowest rates, namely the 

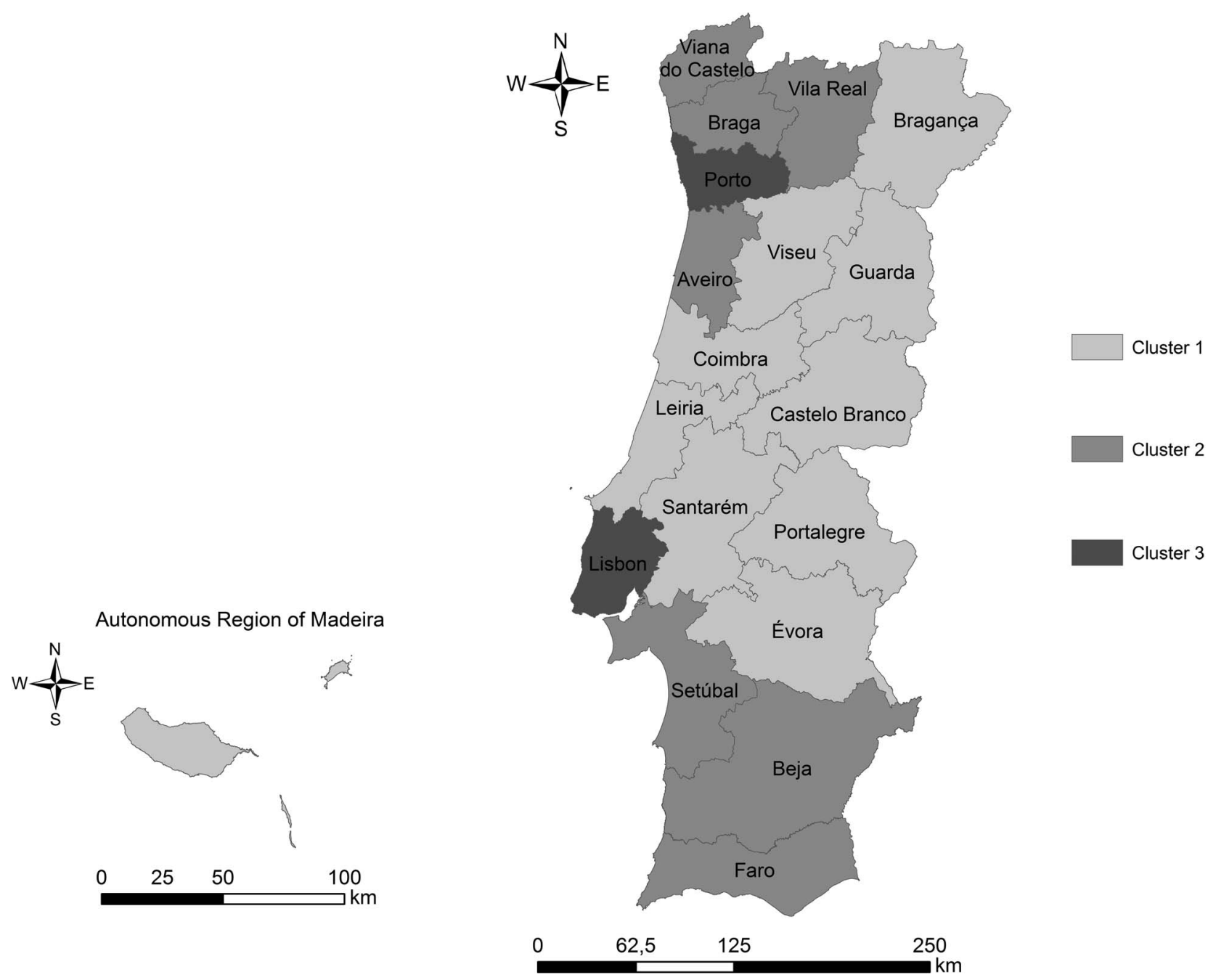

Figure 1 Clusters based on the time profiles of TB incidence rates from the 19 evaluated regions in Portugal. Source: Carta Administrativa Oficial de Portugal 2010, Direção Geral do Território, Lisbon, Portugal.

Archipelago of Madeira, two coastal districts and two sparsely populated continental districts.

As expected, the most populous districts of Porto and Lisbon presented the highest absolute frequencies on every predictor considered. However, in terms of rates, none of the 19 regions was observed to be systematically at the top or bottom of a predictor prevalence. For example, Porto experienced the highest rates of unemployment and the largest proportion of working age population for several years, while the touristic Algarve region presented the highest average rates for the treatment of alcohol and drug dependencies, and Lisbon and Bragança, a northern continental district, alternated with the highest rates of incarceration. The district of Lisbon had the highest HIV notification rate throughout the study. These data are not presented in tabular form here because the data have a longitudinal structure and several predictors were studied.

The statistical classification analysis identified three (longitudinal) patterns. TB incidence rates for each region and the mean trajectory of each cluster are shown in Figure 2. The three time trajectories are all essentially decreasing functions. Cluster 1 comprises the 10 regions with the lowest incidence rates, mainly located in the central region of continental Portugal and the Autonomous Region of Madeira. The districts with the highest incidence rates, namely Porto and Lisbon, gave rise to Cluster 3. Cluster 2 encompasses the remaining seven districts, mainly from northern coastal and southern Portugal. The longitudinal mean incidence rates of Cluster 2 are roughly between the mean incidence rates from Clusters 1 and 3 (Figure 2).

The highest HIV notification rates were observed within Cluster 3 and in some regions of Cluster 2. Until 2008, the mean rates corresponding to Cluster 3 were significantly higher than those of the remaining two clusters, between which there was no statistically significant difference. In all clusters, the mean HIV notification rate decreased with time: the yearly decrease was estimated at 0.42 notified cases per 100000 population $(P>0.05)$ for Cluster $1,0.53(P$ $>0.05)$ for Cluster 2 and $1.39(P<0.05)$ for Cluster 3 (Appendix Figure 2, Appendix Table A.2). 


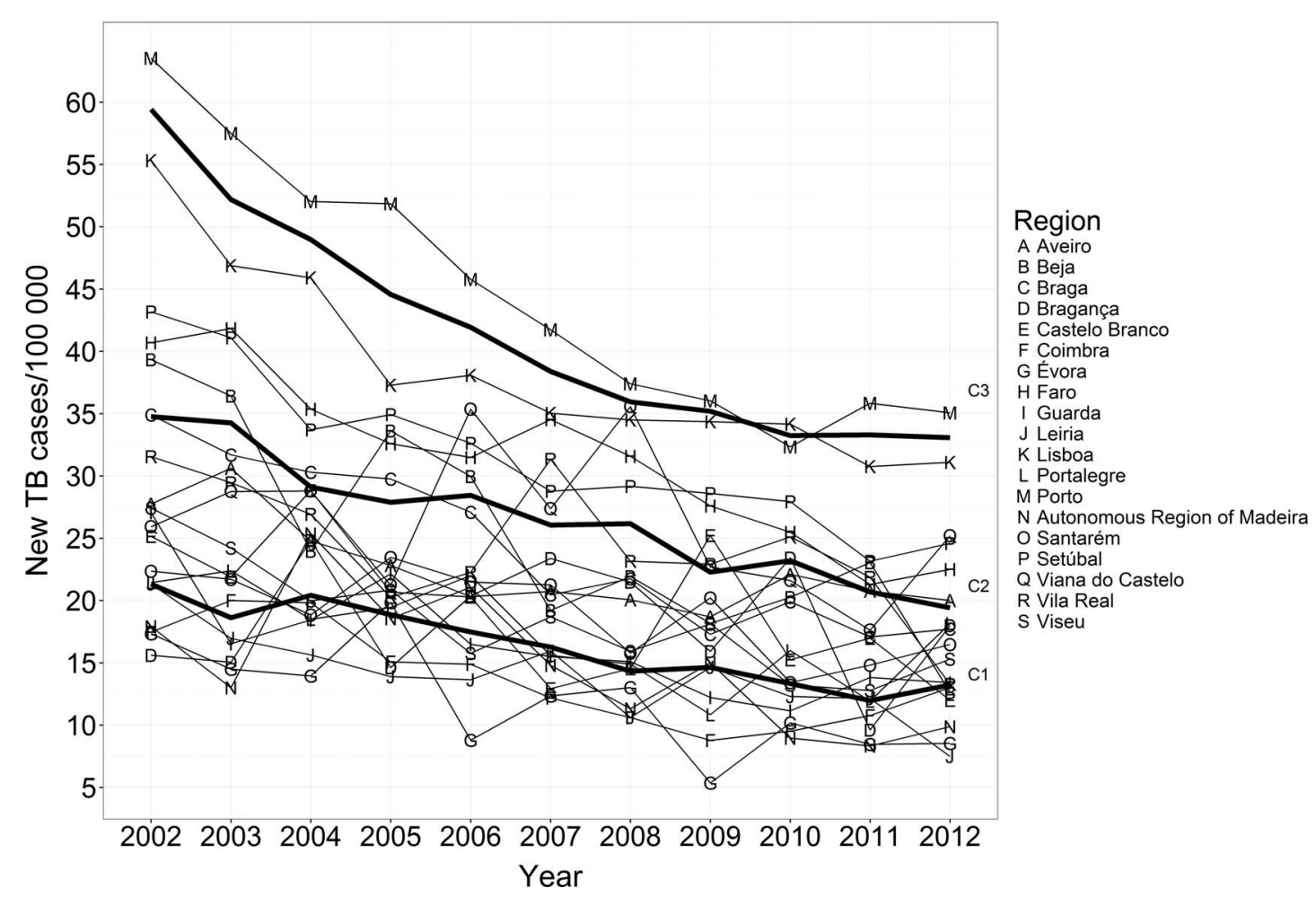

Figure 2 Time evolution of TB incidence rates (per 100000 population) by region and cluster, 2002-2012. TB=tuberculosis; $\mathrm{C} 1=$ mean trajectory of Cluster $1 ; C 2=$ mean trajectory of Cluster 2; C3= mean trajectory of Cluster 3.

The highest unemployment rates were observed in Porto, a Cluster 3 region, and in some regions of Cluster 2. In all clusters, the mean unemployment rates fluctuated with time until 2007, after which they increased in an approximately linear way. In 2012, the rate was double the value observed in 2002. The average yearly increase was estimated at $834.51 /$ $100000(P<0.001)$ in Cluster $1,946.37(P<0.001)$ in Cluster 2 and $5869.30(P<0.001)$ in Cluster 3 (Appendix Figure A.2, Appendix Table A.2).

Among the sociodemographic and health variables analysed, only HIV notifications and unemployment rates were found to have a statistically significant effect on the multiple model for the evolution over time of the TB incidence rate, after adjusting for time and cluster structure (Appendix Table A.3).

The effect of each of the predictors in the final model was interpreted for fixed values of the remaining variables in the model (Appendix Table A.3). Following that structure, 1) an increase of 10 HIV notifications/100 000 was associated with two new TB cases $/ 100000(P<0.05)$, and 2$)$ an increase of 1000 unemployed subjects/100 000 was associated with one new TB case/100 $000(P<0.05)$.

Finally, for any fixed values of the explanatory variables in the model, including time, Cluster 1 (vs. Cluster 3) was expected to have the lowest (vs. highest) average TB incidence rate $(P<0.05)$. Cluster 2 was predicted to lie between the two $(P<0.05)$ (Appendix Figure A.3, Appendix Table A.3).

\section{DISCUSSION}

Our study identified longitudinal trends in the TB incidence rate in Portugal from 2002 to 2012 and assessed the effect of socio-demographic and healthrelated predictors on the time profiles identified. We found three longitudinal patterns of TB incidence in the 19 Portuguese regions evaluated; all clusters essentially featured decreasing trends in incidence. HIV coinfection and unemployment were identified as those factors with the highest impact on TB time profiles.

HIV infection is a well-known risk factor for active TB. ${ }^{13}$ There is a strong spatio-temporal association between $\mathrm{TB}$ and HIV, ${ }^{14}$ even in low-incidence regions. ${ }^{14,15}$ Although the HIV incidence rate in Portugal has declined steadily since 2001, it remains one of the highest in Western Europe, at 13.6/ 100000 . Lisbon, the largest urban centre, had the highest HIV incidence rate in the country, at 31.8/ $100000 .{ }^{16}$ According to our models, HIV notification was the factor with the greatest impact on $\mathrm{TB}$ time profiles.

Several strategies to reduce HIV infection have been implemented in the country. National strategies include free distribution of condoms since 2006 and the syringe exchange programme for drug users established in 1993. Mobile and fixed centres for rapid HIV diagnosis have been used to reduce the time to diagnosis. ${ }^{16}$ To improve diagnosis and treatment adherence, HIV diagnosis and highly active antiretroviral therapy are freely available to all patients, 
including those with non-legal status. Other strategies have been developed to manage hard-to-reach populations, namely drug users, ${ }^{17}$ with improvements in TB detection and treatment completion.

At the end of 2012, the national TB and HIV programmes were fully integrated, and well-defined joint strategies were established. In 2013, $77 \%$ of all TB patients were screened for HIV, and $15 \%$ were positive. ${ }^{16}$ Information on TB screening among HIVpositive patients is lacking; however, data show that in $2013,26 \%$ of patients with the acquired immunedeficiency syndrome (AIDS) had TB as an AIDSdefining disease. ${ }^{16}$

In our study, unemployment was also positively associated with increased TB incidence. This finding may be related to the socio-economic and demographic profiles often linked to the unemployed, including low income, poor access to health care and poor nutrition. Unemployment has been associated with increased risk of TB. ${ }^{9,10,18-20}$

Our study had some limitations. Due to lack of data from other institutions for some years, it was not possible to include all variables of interest, such as the homeless, those on minimum social welfare, the foreign-born and those dependent on alcohol or drugs. Second, although the model assumed non-zero correlations between observations from different years, in practice this time dependence referred to the infectious period. In Portugal, the median time between the onset of symptoms and diagnosis ranges from 36 to 92 days. $^{21,22}$ The analysis could be enhanced by the use of shorter intervals; however, most of the data would not be available. The Portuguese HIV surveillance system also suffers from some classical problems: reporting delays in the notification process, mainly in the most recent diagnosis, and underreporting of cases. ${ }^{23}$ The HIV notification and TB incidence rates may therefore be biased. Furthermore, the absence of molecular epidemiology limits the present analysis to associations between notifications, without insights into the contribution of HIV to TB transmission and into the enhanced susceptibility of HIV patients to progress rapidly to TB disease. Finally, it was not possible to determine the prison establishment for $1-2 \%$ of the inmates for each year.

The strengths of the study include the TB case detection rate in Portugal (84-93\%) during the period studied: ${ }^{1}$ this longitudinal study covered 11 years and about 35000 reported cases of active TB, and almost the entire national territory, except for the Azores. Finally, it should be highlighted that we crosschecked data from several national institutions.

Our findings have important public health implications, and support the view that combined TB-HIV strategies and improvements in social determinants can contribute to the decrease in TB incidence.

\section{Acknowledgements}

ARG was partially funded by the European Regional Development Fund through the COMPETE Programme and by the Portuguese Government through the Fundação para a Ciência e a Tecnologia under the PEst project (C/MAT/UI0144/2013).

Conflicts of interest: none declared.

\section{References}

1 World Health Organization. Global tuberculosis report, 2014. WHO/HTM/TB/2014.08. Geneva, Switzerland: WHO, 2014.

2 Direcção Geral da Saúde. Programa Nacional de Luta Contra a Tuberculose. Ponto da situação epidemiológica e de desempenho (dados provisórios em Março de 2013). Lisboa, Portugal: Direcção Geral da Saúde, 2013. http://www.dgs.pt/? cr=24067. Accessed April 2016. [Portuguese]

3 European Centre for Disease Prevention and Control/WHO Regional Office for Europe. Tuberculosis surveillance and monitoring in Europe, 2014. Stockholm, Sweden: ECDC, 2014.

4 de Vries G, Aldridge R W, Cayla J A, et al. Epidemiology of tuberculosis in big cities of the European Union and European Economic Area countries. Euro Surveill 2014; 19: 20726.

5 Nunes C. Tuberculosis incidence in Portugal: spatiotemporal clustering. Int J Health Geogr 2007; 6: 30.

6 Harling G, Castro M C. A spatial analysis of social and economic determinants of tuberculosis in Brazil. Health Place 2014; 25: 56-67.

7 Sperli Geraldes Marin dos Santos N, Sperli Geraldes Santos MdL, Figueiredo Vendramini S H, et al. Tuberculose e análise espacial: revisão da literatura. Ciencia Enferm 2014; 20: 117129. [Portuguese]

8 San Pedro A, Oliveira R Md. Tuberculose e indicadores socioeconômicos: revisão sistemática da literatura. Rev Panam Salud Publica 2013; 33: 294-301. [Portuguese]

9 Gómez-Barroso D, Rodríguez Valín E, Flores Segovia V, Ramis Prieto R, Barrio Fernández J Ld, Simón Soria F. Distribución espacial de la tuberculosis en España mediante métodos geoestadísticos. Rev Esp Salud Pública 2009; 83: 737-744. [Spanish]

10 Couceiro L, Santana P, Nunes C. Pulmonary tuberculosis and risk factors in Portugal: a spatial analysis. Int J Tuberc Lung Dis 2011; 15: 1445-1454, i.

11 Genolini C, Falissard B. KmL: k-means for longitudinal data. Comput Stat 2010; 25: 317-328.

12 Maulik U, Bandyopadhyay S. Performance evaluation of some clustering algorithms and validity indices. IEEE Trans Pattern Anal Mach Intell 2002; 24: 1650-1654.

13 Narasimhan P, Wood J, MacIntyre C R, Mathai D. Risk factors for tuberculosis. Pulm Med 2013; 2013: 11.

14 Corbett E L, Watt C J, Walker N, et al. The growing burden of tuberculosis: global trends and interactions with the HIV epidemic. Arch Intern Med 2003; 163: 1009-1021.

15 DeRiemer K, Kawamura L M, Hopewell P C, Daley C L. Quantitative impact of human immunodeficiency virus infection on tuberculosis dynamics. Am J Respir Crit Care Med 2007; 176: 936-944.

16 Direcção Geral da Saúde. Portugal: infeção VIH, SIDA e tuberculose em números - 2014. Lisbon, Portugal: Direcção Geral da Saúde, 2014. http: //www.dgs.pt/estatisticas-de-saude/ estatisticas-de-saude/publicacoes/portugal-infecao-vih-sida-etuberculose-em-numeros-2014.aspx. Accessed April 2016. [Portuguese]

17 Duarte R, Santos A, Mota M, Carvalho A, Marques A, Barros H. Involving community partners in the management of tuberculosis among drug users. Public Health 2011; 125: 60-62.

18 Munch Z, Van Lill S W, Booysen C N, Zietsman H L, Enarson D A, Beyers N. Tuberculosis transmission patterns in a high- 
incidence area: a spatial analysis. Int J Tuberc Lung Dis 2003; 7: 271-277.

19 Coker R, McKee M, Atun R, et al. Risk factors for pulmonary tuberculosis in Russia: case-control study. BMJ 2006; 332: 8587.

20 Ladefoged K, Rendal T, Skifte T, Andersson M, Soborg B, Koch A. Risk factors for tuberculosis in Greenland: case-control study. Int J Tuberc Lung Dis 2011; 15: 44-49.

21 Areias V, Neves I, Carvalho A, Duarte R. Mycobacterium tuberculosis, how long did you walk? Rev Port Pneumol 2013; 19: 139-140.
22 Guimarães M, Oliveira O, Teixeira C, Gaio R, Duarte R. Atraso no diagnóstico da tuberculose. Barreiras de acesso aos cuidados de saúde. Oporto, Portugal: Faculdade de Medicina da Universidade do Porto, 2014. [Portuguese]

23 Oliveira A, Costa J, Gaio A R, eds. The incidence of AIDS in Portugal adjusted for reporting delay and underreporting. $9^{\text {th }}$ Iberian Information Systems and Technologies (CISTI) Conference, Barcelona, Spain, 18-21 June 2014: pp 1-5. $\mathrm{http}: / /$ ieeexplore.ieee.org/stamp/stamp.jsp?tp=\&arnumber= 6877056\&isnumber=6876860 Accessed April 2016. 


\section{APPENDIX}

Table A.1 Data source of variables analysed

\begin{tabular}{ll}
\hline Variable & \multicolumn{1}{c}{ Source } \\
\hline $\begin{array}{l}\text { Working age population } \\
\text { Elderly population }\end{array}$ & INE, annual estimates of resident population at the municipal and age group level, 2002-2012 \\
Resident population & INE, annual estimates of resident population at the municipal and age group level, 2002-2012 \\
Unemployment & INE, annual estimates of resident population at the municipal and age group level, 2002-2012 \\
Incarceration & IEFP, the publications 'Employment Offices Statistics' and 'Monthly Statistics by City', 2002-2012 \\
Prison overcrowding & DGSP, capacity and existing inmates on 31 December 2002-2012 \\
Alcohol or other drugs & DGSP, capacity and existing inmates on 31 December 2002-2012 \\
& IDT, annual reports 'The Drugs and Drug Addiction Situation in the Country', information at the district \\
& level, 2002-2011. In 2012, the available data referred only to patients with problems related to drug \\
HIV infection & abuse. The value for 2012 was therefore estimated by calculating the mean of 2010 and 2011 \\
Physicians & INSA, notified cases of HIV infection, 2002-2012 \\
Medical appointments & INE, number of physicians at the municipal level, 2002-2012 \\
\hline
\end{tabular}

INE = Instituto Nacional de Estatística (Statistics Portugal); IEFP = Instituto do Emprego e Formação Profissional (Employment and Vocational Training Institute); DGSP = Direcção Geral Dos Serviços Prisionais (Directorate General of Prison Services); IDT = Instituto da Droga e da Toxicodependência (Institute of Drugs and Drug Addiction); HIV = human immunodeficiency virus; INSA = Instituto Nacional de Saúde Doutor Ricardo Jorge (Doutor Ricardo Jorge National Health Institute).

Table A.2 Estimates identified by the longitudinal models for HIV notification and unemployment rates, 2002-2012. Cluster 3 was used as the reference category

\begin{tabular}{lccr}
\hline Variable & Coefficient & Standard error & $P$ value \\
\hline Evolution in time of the HIV notification rate & & \\
Intercept & 35.43 & 4.59 & $<0.001$ \\
Cluster 1 & -25.81 & 5.03 & $<0.001$ \\
Cluster 2 & -20.16 & 5.21 & $<0.001$ \\
Time (= year-1)* & -1.39 & 0.52 & 0.008 \\
Time*Cluster 1 & 0.97 & 0.57 & 0.091 \\
Time*Cluster 2 & 0.86 & 0.59 & 0.145 \\
Evolution in time of unemployment rates & & \\
Intercept & 73792.49 & 8022.79 & $<0.001$ \\
Cluster 1 & -66458.02 & 8757.08 & $<0.001$ \\
Cluster 2 & -53225.60 & 9025.07 & $<0.001$ \\
Time (= year-1)* & 5869.30 & 511.72 & $<0.001$ \\
Time*Cluster 1 & -5034.79 & 559.19 & $<0.001$ \\
Time*Cluster 2 & -4922.93 & 562.89 & $<0.001$ \\
\hline
\end{tabular}

* Years 2002, 2003,... 2012 were coded 1, 2, ..11.

HIV = human immunodeficiency virus.
Table A.3 Estimates from the multiple model for the evolution in time of tuberculosis incidence rates, 2002-2012. Cluster 3 was used as the reference category

\begin{tabular}{lccr}
\hline Variable & Coefficient & Standard error & $P$ value \\
\hline Intercept & 41.48 & 4.41 & $<0.001$ \\
HIV notification rate & 0.20 & 0.08 & 0.010 \\
Unemployment rate & 0.001 & 0.0005 & 0.002 \\
Cluster 1 & -26.09 & 3.67 & $<0.001$ \\
Cluster 2 & -16.84 & 3.45 & $<0.001$ \\
Time (= year-1)* & -2.60 & 0.46 & $<0.001$ \\
Time*Cluster 1 & 1.34 & 0.49 & 0.007 \\
Time*Cluster 2 & 0.96 & 0.5 & 0.056
\end{tabular}

* Years 2002, 2003,... 2012 were coded 1, 2, ...11.

$\mathrm{HIV}=$ human immunodeficiency virus. 


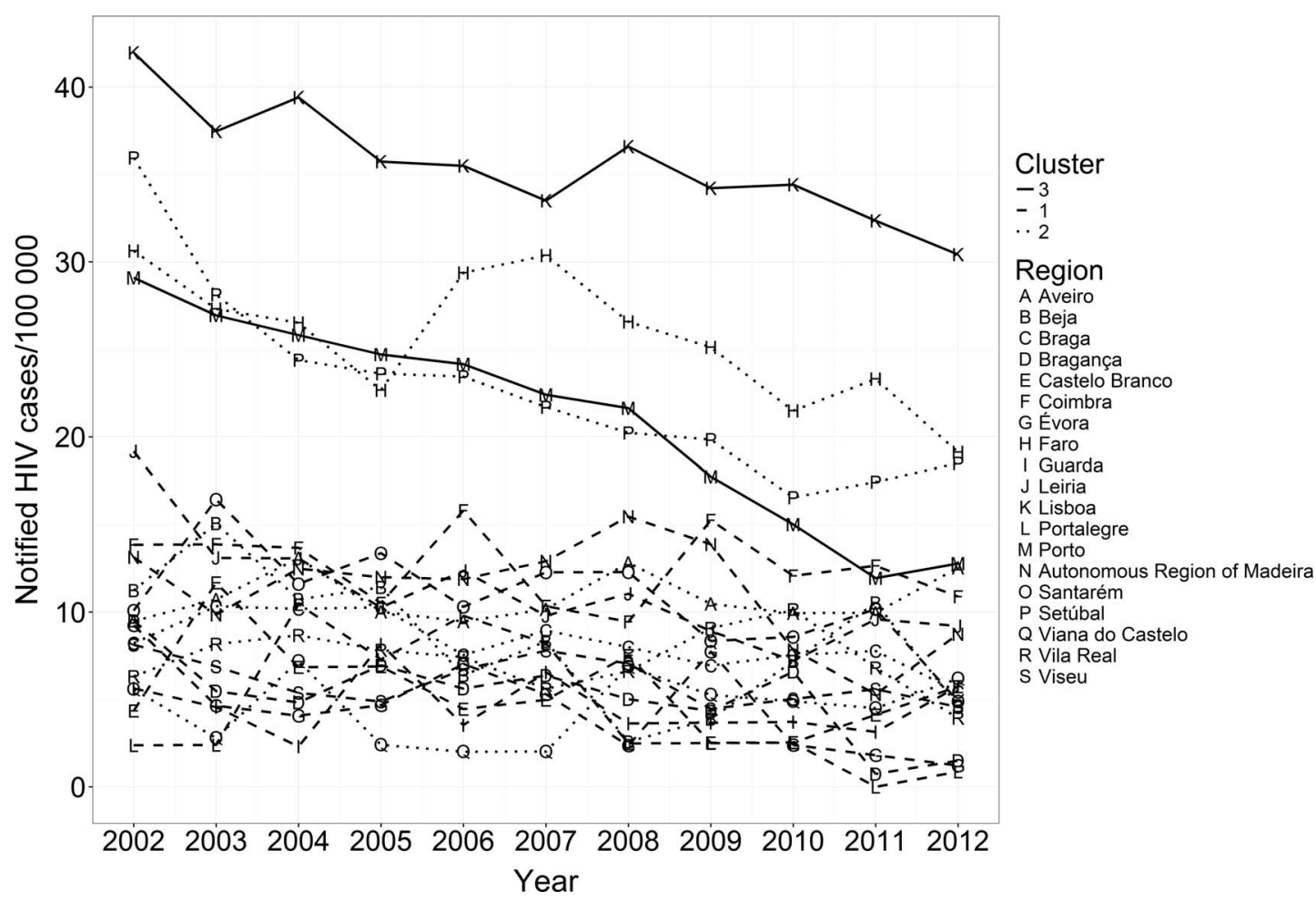

Figure A.1 Time evolution of HIV notification rates (per 100000 population) by cluster and region, 2002-2012. Source: INSA = National Health Institute Doutor Ricardo Jorge, Lisbon, Portugal. HIV = human immunodeficiency virus.

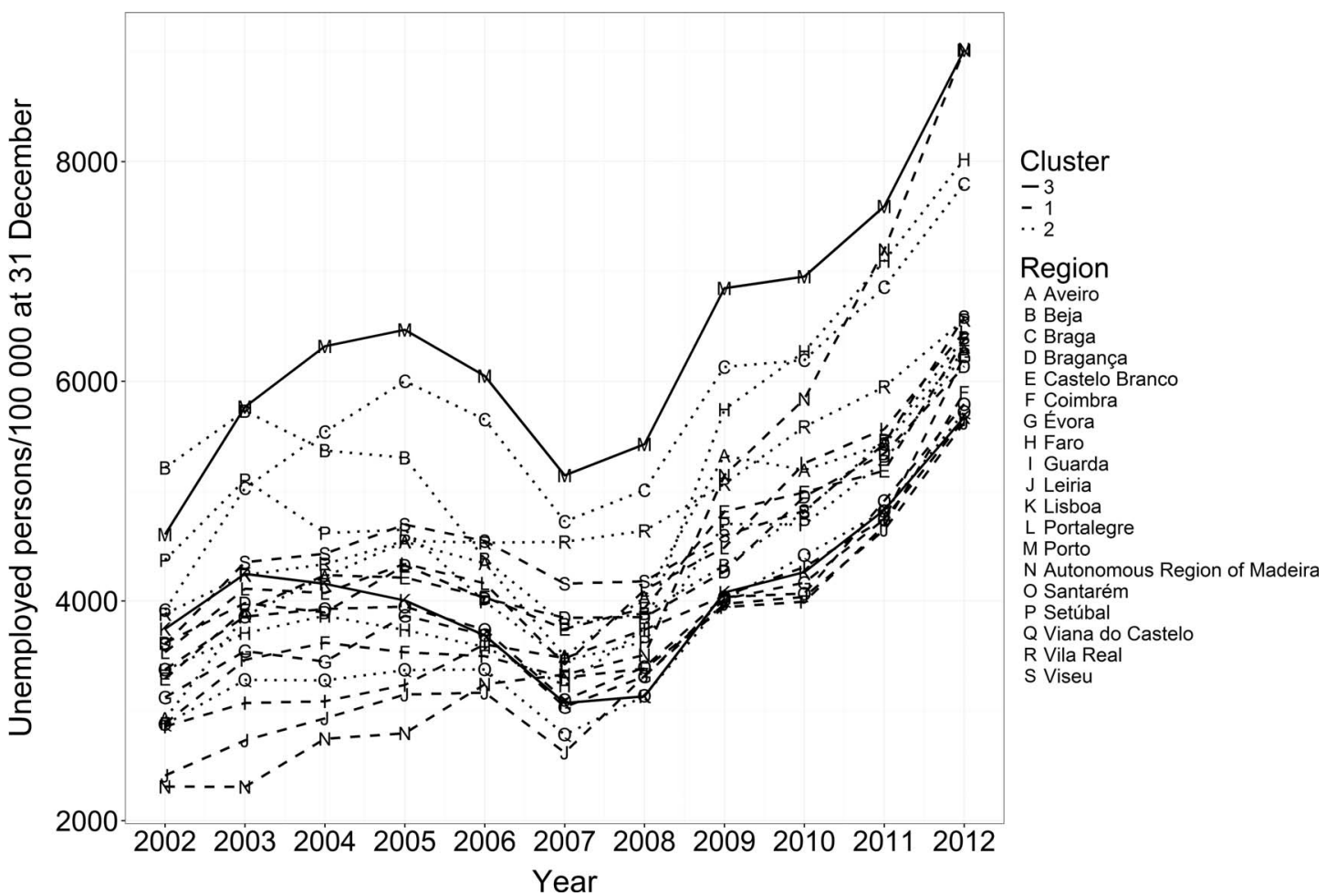

Figure A.2 Time evolution of unemployment rates (per 100000 population) by cluster and region, 2002-2012. Source: Instituto do Emprego e Formação Profissional, Lisbon, Portugal. 


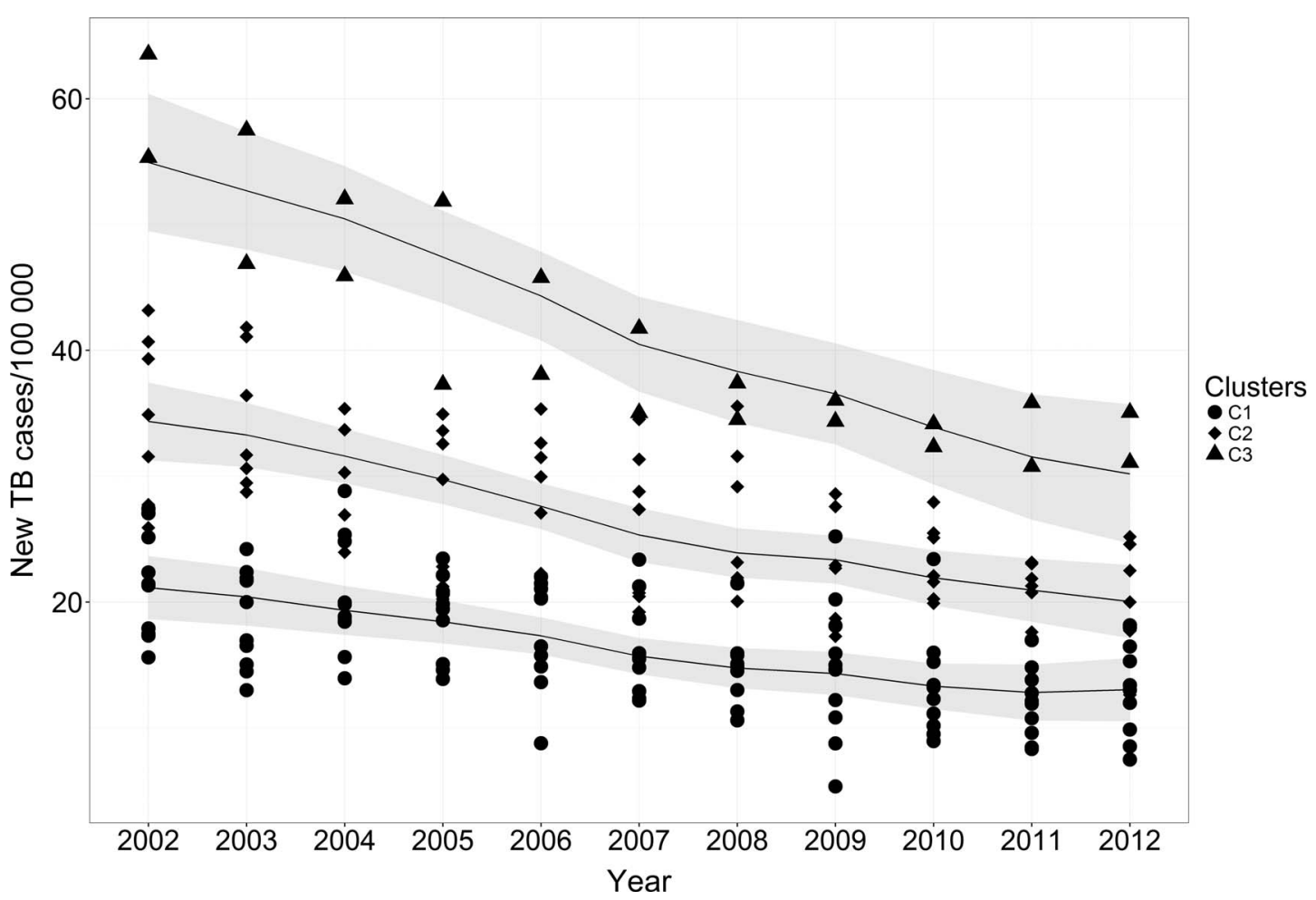

Figure A.3 Expected values for TB incidence rates (per 100000 population) for the sample averages of the HIV notification and unemployment rates (per 100000 population) by cluster, 2002-2012. TB = tuberculosis; HIV = human immunodeficiency virus. 
CADRE : Le Portugal reste le pays d'Europe de l'Ouest qui a l'incidence de tuberculose (TB) la plus élevée.

OBJECTIF : Identifier les tendances longitudinales de l'incidence de la TB au Portugal de 2002 à 2012 et étudier l'effet longitudinal des indicateurs sociodémographiques et sanitaires de la population résidente sur le taux d'incidence de la TB.

MÉTHODE : Nous avons utilisé les données du système national de surveillance de la TB et d'autres institutions nationales. L'algorithme de regroupement longitudinal des moyennes a été réalisé sur le profil d'incidence dans le temps de la TB dans les districts du Portugal.

RÉSULTATS : Trois profils longitudinaux relatifs au taux d'incidence de la TB au Portugal ont été identifiés. Dans les trois cas, l'incidence de la TB a décru avec le temps. Parmi tous les indicateurs sociodémographiques et sanitaires qui ont été étudiés, le taux de notification du virus de l'immunodéficience humaine (VIH) et le chômage se sont avérés avoir un effet positif significatif sur l'incidence de la TB. L'effet a, en particulier, été le plus élevé pour le taux de notification du VIH.

CONCLUSION : Notre étude soutient le fait que des stratégies combinées vis-à-vis de la TB et du VIH et l'amélioration des déterminants sociaux peuvent contribuer à la diminution de l'incidence de la TB.
MARCO De referencia: El Portugal sigue siendo el país con la más alta incidencia de tuberculosis (TB) en Europa occidental.

O B JETIV OS: Determinar la evolución longitudinal de la incidencia de TB en el Portugal del 2002 al 2012 e investigar el efecto longitudinal de los determinantes sociodemográficos y los relacionados con la salud de la población residente, en la tasa de incidencia de TB.

METODOS: Se utilizaron los datos del Sistema Nacional de Vigilancia de la Tuberculosis y de otras instituciones nacionales. Se aplicó el algoritmo de partición K-medias para el análisis de los datos longitudinales de las curvas de incidencia frente al tiempo en los distritos de Portugal.

RESULTADOS: Se detectaron tres patrones longitudinales en la tasa de incidencia de TB. En los tres casos la incidencia disminuyó con el transcurso del tiempo. De todos los factores sociodemográficos y relacionados con la salud que se estudiaron, la tasa de notificación de la infección por el virus de la inmunodeficiencia humana (VIH) y el desempleo ejercieron un efecto significativo positivo en la incidencia de TB. Los efectos de mayor magnitud correspondieron a la tasa de notificación de la infección por el VIH.

CONCLUSION: Los resultados del estudio respaldan la pertinencia de la utilización de las estrategias integradas de atención de la TB y la infección por el VIH y el mejoramiento de los determinantes sociales. 